\title{
The potential of elastic and polarization lidars to retrieve extinction profiles
}

\author{
Elina Giannakaki ${ }^{1,2}$, Panos Kokkalis ${ }^{3,4}$, Eleni Marinou ${ }^{4,5}$, Nikolaos S. Bartsotas ${ }^{6}$, Vassilis Amiridis $^{4}$, \\ Albert Ansmann ${ }^{7}$, and Mika Komppula ${ }^{2}$ \\ ${ }^{1}$ Department of Environmental Physics and Meteorology, University of Athens, Athens 15784, Greece \\ ${ }^{2}$ Finnish Meteorological Institute, Atmospheric Research Centre of Eastern Finland, Kuopio, 70211, Finland \\ ${ }^{3}$ Physics Department, Faculty of Science, Kuwait University, Kuwait City, Kuwait \\ ${ }^{4}$ Institute for Astronomy, Astrophysics, Space Applications and Remote Sensing, \\ National Observatory of Athens, Athens 15236, Greece \\ ${ }^{5}$ Institute of Atmospheric Physics, German Aerospace Center (DLR), 82234 Oberpfaffenhofen, Germany \\ ${ }^{6}$ Atmospheric Modeling and Weather Forecasting Group, Department of Physics, \\ National and Kapodistrian University of Athens, Athens, Greece \\ ${ }^{7}$ Leibniz Institute for Tropospheric Research (TROPOS), 04318 Leipzig, Germany
}

Correspondence: Elina Giannakaki (elina@phys.uoa.gr)

Received: 9 July 2019 - Discussion started: 7 October 2019

Revised: 23 December 2019 - Accepted: 9 January 2020 - Published: 21 February 2020

\begin{abstract}
A new method, called ElEx (elastic extinction), is proposed for the estimation of extinction coefficient lidar profiles using only the information provided by the elastic and polarization channels of a lidar system. The method is applicable to lidar measurements both during daytime and nighttime under well-defined aerosol mixtures. ElEx uses the particle backscatter profiles at $532 \mathrm{~nm}$ and the vertically resolved particle linear depolarization ratio measurements at the same wavelength. The particle linear depolarization ratio and the lidar ratio values of pure aerosol types are also taken from literature. The total extinction profile is then estimated and compared well with Raman retrievals. In this study, ElEx was applied in an aerosol mixture of marine and dust particles at Finokalia station during the CHARADMExp campaign. Any difference between ElEx and Raman extinction profiles indicates that the nondust component could be probably attributed to polluted marine or polluted continental aerosols. Comparison with sun photometer aerosol optical depth observations is performed as well during daytime. Differences in the total aerosol optical depth are varying between $1.2 \%$ and $72 \%$, and these differences are attributed to the limited ability of the lidar to correctly represent the aerosol optical properties in the near range due to the overlap problem.
\end{abstract}

\section{Introduction}

Aerosols play an important role in the atmospheric radiation budget (IPCC, 2013). Depending on the aerosol type, they can absorb or scatter the incoming and outgoing radiation, warming or cooling the atmosphere; depending on their size and composition, they can act as cloud condensation nuclei, modifying cloud physical and radiative properties (Kauffman et al., 2002). However, climate forcing by tropospheric aerosols remains one of the largest uncertainties in climate variability and climate change studies. Pure types of aerosols can be categorized roughly as mineral dust, sea salt, volcanic, carbonaceous, or sulfate aerosols originating from various natural and anthropogenic sources.

Several lidar studies have revealed that a broad variety of aerosol mixtures occurs in the European continent (e.g., Balis et al., 2004; Papayannis et al., 2005). The mixing occurs because of the relatively long pathways of air masses across different aerosol source regions before detection over the European continent. Sea-salt particles are near-spherical and nonabsorbing particles, whereas dust particles are nonspherical and show considerable absorption. Thus mixing of either marine aerosol or absorbing aerosol, or both, with dust particles may result in different optical properties. The measured op- 
tical properties are then differentiated from the contribution of each aerosol type to the total aerosol load.

Lidar measurements provide vertical profiling of various particle properties with high spatial and temporal resolutions, and based on the optical properties the identification of different aerosol types becomes feasible. The determination of the extinction-to-backscatter ratio (the so-called lidar ratio) profile is possible using the Raman-based lidar technique (Ansmann et al., 1992). The lidar ratio contains information on the aerosol type, since it depends on the index of refraction and on the size of particles. Many studies have demonstrated that the lidar ratio is a quantity valuable for aerosol characterization (Ansmann et al., 2002; Müller et al., 2007; Mattis et al., 2004; Amiridis et al., 2005; Giannakaki et al., 2010, 2016; Groß et al., 2011, $2013,2015)$. However, the majority of aerosol lidars, including the recently launched Cloud-Aerosol Lidar and Infrared and Pathfinder Satellite Observations (CALIPSO) lidar, are so-called elastic backscatter lidars. Such lidars allow us to retrieve only the particle backscatter coefficient (Klett, 1981). Elastic backscatter lidars are often equipped with polarization measurements.

Recently, the polarization lidar technique has been additionally used to separate the desert dust aerosol component from other aerosol components (Tesche et al., 2009). Desert dust causes high depolarization of backscattered light, whereas typical nondesert aerosol mixtures, like marine aerosols, lead to very low depolarization. The technique is the base of the POLIPHON algorithm for ground-based lidars (Ansmann et al., 2019), and it has also been applied to CALIPSO aerosol profiles either on selected case studies (Giannakaki et al., 2011) or on a statistical basis (Marinou et al., 2017).

In this contribution, we propose a method to determine the extinction coefficient profile using only the elastic and polarization lidar channels at $532 \mathrm{~nm}$. The method has been first suggested by Giannakaki et al. (2017) and further applied by Ansmann et al. (2017). In this contribution, we fully outline the methodology providing an extended sensitivity analysis along with the main advantages and limitations of it. The methodology is limited to cases where only two basic aerosol types are observed and the mixing state of the atmosphere is well known. When the abovementioned criteria are met, extinction coefficient profiles can be retrieved with non-Raman lidars, even during daytime and with low time resolution windows of $1 \mathrm{~h}$ or less. In the case of a more complicated aerosol mixture inside the planetary boundary layer, our method is still valid and applicable to free tropospheric aerosol layers.

\section{Methodology}

\subsection{Elastic extinction retrieval: the ElEx methodology}

A new method, called ElEx (elastic extinction), is proposed for the estimation of extinction coefficient lidar profiles using only the information provided by the elastic and polarization channels of a lidar system.

\subsubsection{Backscatter coefficient and particle depolarization profile}

At the first step, we retrieve the backscatter coefficient $\left(\beta_{t}\right)$ at $532 \mathrm{~nm}$. The lidar equation for the backscatter coefficient at the emitted wavelengths is solved following the KlettFernald retrieval methods (Klett, 1981). For the calibration of the profile of the measured $532 \mathrm{~nm}$ elastic backscatter signal, pure Rayleigh signals are simulated based on actual temperature and pressure profiles from numerical weather forecast data or actual nearby radiosonde observations. The measured $532 \mathrm{~nm}$ signals are then fitted to the Rayleigh signal profile in the aerosol-free middle-to-upper troposphere. The solution is possible only under the assumption of a constant with height relation between aerosol extinction and backscatter coefficient (lidar ratio). The assumed lidar ratio can be selected either from climatological studies or, if available, from nighttime measurements. Additional information provided from dust models, backward trajectories, sun photometers, and/or satellite retrievals may be helpful for the right selection of the initial lidar ratio value. ElEx also uses the particle depolarization ratio at $532 \mathrm{~nm}$. The particle depolarization ratio is computed from the volume depolarization ratio by means of the determined particle backscatter coefficient (Freudenthaler et al., 2009).

\subsubsection{Separation of the backscatter profile}

At the second step we need to decompose our profile into its aerosol components, assuming that only two aerosol types are observed. The procedure to separate the aerosol mixture into two components starts from the equation of the particle depolarization ratio:

$\delta_{p}=\frac{\beta_{1}^{\perp}+\beta_{2}^{\perp}}{\beta_{1}^{\|}+\beta_{2}^{\perp}}$.

$\beta^{\perp}$ and $\beta^{\|}$are so-called cross- and parallel-polarized particle backscatter coefficients, respectively, that can in principle be computed from the lidar return signals detected with the cross-polarized and parallel-polarized signal channels.

As shown by Tesche et al. (2009), the separation of the two aerosol components is possible through the simple Eq. (2):

$\beta_{1}=\beta_{t} \frac{\left(\delta_{t}-\delta_{2}\right)\left(1+\delta_{1}\right)}{\left(\delta_{1}-\delta_{2}\right)\left(1+\delta_{t}\right)}$.

In order to perform the decomposition of the backscatter profile, the two aerosol types should be distinguishable in terms 
Table 1. Overview of the input parameters used in our study.

\begin{tabular}{|c|c|c|c|c|}
\hline Parameter & Aerosol type & Symbol & Value & Reference \\
\hline \multirow[t]{2}{*}{ Lidar ratio at $532 \mathrm{~nm}$} & Marine & $\operatorname{lr}_{m}$ & $25 \mathrm{sr}$ & $\begin{array}{l}\text { Müller et al. (2007); Dawson et al. (2015); } \\
\text { Groß et al. }(2011,2013,2015)\end{array}$ \\
\hline & Saharan dust & $\operatorname{lr}_{d}$ & $55 \mathrm{sr}$ & $\begin{array}{l}\text { Mattis et al. 2002; Mona et al. (2006); } \\
\text { Papayannis et al. (2005); Balis et al. (2004); } \\
\text { Groß et al. (2011, 2013, 2015) }\end{array}$ \\
\hline \multirow{2}{*}{$\begin{array}{l}\text { Particle depolarization } \\
\text { ratio at } 532 \mathrm{~nm}\end{array}$} & Marine & $\delta_{m}$ & 0.05 & Groß et al. $(2011,2013,2015)$ \\
\hline & Saharan dust & $\delta_{d}$ & 0.31 & $\begin{array}{l}\text { Freudenthaler et al. (2009); } \\
\text { Groß et al. }(2011,2013,2015)\end{array}$ \\
\hline
\end{tabular}

of the particle depolarization ratio. This means that the decomposition is possible using the information of the strongly depolarizing dust and a second aerosol type with less depolarizing ability, like marine, pollution, or even biomass burning aerosols.

From the profile of the total particle backscatter coefficient $\beta_{t}$ and the backscatter coefficient of the first aerosol type $\beta_{1}$, we calculate the remaining backscatter coefficient of the second aerosol type.

$\beta_{2}=\beta_{t}-\beta_{1}$

\subsubsection{Estimation of elastic extinction profile}

The separation of the backscatter profile gives us the opportunity to calculate the total extinction coefficient by applying the correct lidar ratio to each aerosol component.

$a_{t}=a_{1}+a_{2}=\beta_{1} \cdot \operatorname{lr}_{1}+\beta_{2} \cdot \operatorname{lr}_{2}$

This is only possible in the case of the mixture of two aerosol types that are well known in terms of lidar ratio. ElEx is presented in the flowchart of Fig. 1. Types 1 and 2 could be any aerosol type that can be distinguishable is terms of depolarization and lidar ratio values. Since the ElEx methodology is strongly dependent on the selection of pure lidar ratio and particle depolarization values, we briefly present the aerosol types that are mostly observed in Europe along with their intensive optical properties.

Continental polluted aerosols are typically small and do not significantly depolarize the backscattered light $\left(\delta_{\text {aer }}^{532}=\right.$ $0.04 \pm 0.04)$ (Heese et al., 2016), and, due to the high carbon content, these particles reveal high lidar ratios (Giannakaki et al., 2010). On the contrary, the clean continental type differentiates from the polluted continental type due to its fewer light-absorbing properties. The clean continental type shows low depolarizing ability with values lower than 0.07 (Omar et al., 2009) and low lidar ratio values, i.e., 20-40 sr (Ansmann et al., 2001; Giannakaki et al., 2010).

In the absence of significant transport of continental aerosols, particles over the remote oceans are largely of marine origin (Prospero et al., 1989). The sea-salt particles feature a predominant coarse mode; however, they are spherical in humid conditions and weakly absorbing, in contrast to the dust particles. Therefore, they yield low particle lidar ratio values, are almost non-depolarizing, and exhibit low particle depolarizing ratio values (Burton et al., 2013; Dawson et al., 2015). Sea-salt particles are mainly identifiable by the low particle lidar ratio, i.e., $15-25 \mathrm{sr}$ at $532 \mathrm{~nm}$ (Burton et al., 2012).

Desert areas around the world emit huge quantities of dust aerosols, which also actually extend considerably over adjacent regions, such as oceans (Jaenicke et al., 1978), and can be transported over very long distances (Prospero et al., 1989; Papayannis et al., 2008; Mona et al., 2012). The optical properties of dust particles are considerably different from the other types, thus making them easy to identify, especially in the absence of aerosol mixtures. However, it needs to be taken into account that the dust optical properties depend on the source region and the transport pattern (Valenzuela et al., 2014), which is a source of variability mainly detected in the lidar ratio (Nisantzi et al., 2015). Recently, Mamouri et al. (2013) showed that dust originating from the Arabian Desert produced significantly lower lidar ratio values $(34-39 \mathrm{sr}$ at $532 \mathrm{~nm})$ than respective values $(50-60 \mathrm{sr}$ at $532 \mathrm{~nm}$ ) from western Saharan dust particles.

Biomass burning is a major global source of atmospheric aerosols. Generally, smoke particles are relatively small, spherical, and highly absorbing that produce low depolarization and large lidar ratios (Amiridis et al., 2009; Baars et al., 2012; Nicolae et al., 2013; Giannakaki et al., 2016). The optical properties of smoke particles may vary due to the vegetation type of the emitting source, the combustion type (smouldering or flaming fires), and atmospheric conditions (Balis et al., 2003). Furthermore, the particles are susceptible to changes in their optical properties during their lifetime in the atmosphere (Nicolae et al., 2013). The similarities of the physical characteristics of smoke particles and continental particles result in similar optical properties, making these types difficult to distinguish.

Volcanoes are another important source of atmospheric aerosols. Volcanic eruptions eject vast amounts of material into the atmosphere (tephra), and the fraction smaller than 


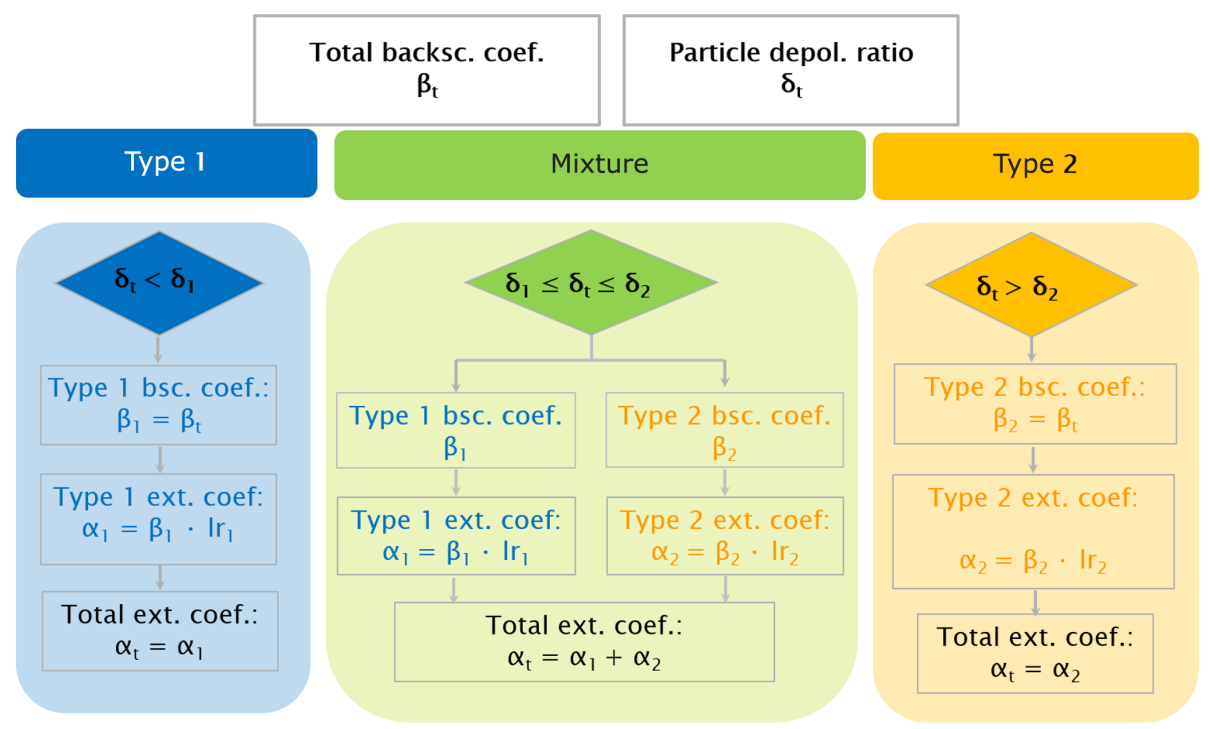

Figure 1. Flowchart of the proposed methodology for the retrieval of extinction coefficient profile using backscatter and depolarization data.

$2 \mathrm{~mm}$ is labeled as volcanic ash. Most of these aerosols will settle only a few tens of kilometers away from the volcano, but smaller particles can travel thousands of kilometers and affect wider areas (Mattis et al., 2010; Sicard et al., 2012; Papayannis et al., 2012; Kokkalis et al., 2013; Pappalardo et al., 2013). The optical properties of volcanic ash aerosols are generally similar to those of desert dust, as was shown by Ansmann et al. (2011) and Wiegner et al. (2012) for fresh ash with particle linear depolarization ratios reaching 0.37 and lidar ratios of 50-65 sr. Aged volcanic particles as observed by Papayannis et al. (2012) indicate higher sphericity and less nonsphericity with depolarization ratio values of about $0.1-0.25$ and lidar ratios within the range 55-67 sr for $355 \mathrm{~nm}$ and $76-89 \mathrm{sr}$ for $532 \mathrm{~nm}$.

ElEx is not limited to nighttime Raman observations, and thus it is also applicable to daytime lidar measurements as long as the observed aerosol types have different particle depolarization ratios to permit an accurate separation between them. The more the particle depolarization ratio between the two aerosol types differs, the better the separation. The accuracy of the extinction coefficient is also dependent on knowledge of the correct lidar ratio. For example, the intensive properties of marine and Saharan dust particles are already well defined, while smoke particles are characterized by large variability, especially for lidar ratio values. In the case of Raman extinction profile availability, the purity of the nondust component can be additionally checked. In stations with more complicated aerosol mixtures within the planetary boundary layer, it is possible to apply the methodology to free tropospheric aerosol layers. This is particularly useful in the case of free tropospheric layers of dust or volcanic particles with smoke or pollution.

\subsection{Description of the lidar system and lidar data processing}

The main instrument of this paper is the Polly ${ }^{\mathrm{XT}}$ lidar as it is described by Althausen et al. (2009) and Engelmann et al. (2016). An overview of PollyNET can be found in Baars et al. (2016). Polly XT works with a Nd:YAG laser, emitting pulses at 1064, 532, and $355 \mathrm{~nm}$, with a repetition frequency of $20 \mathrm{~Hz}$. The receiver consists of a Newtonian telescope, with a diameter of $300 \mathrm{~mm}$ and a field of view of $1 \mathrm{mrad}$. Photomultiplier tubes are used for the detection of the elastically backscattered photons at 355,532 , and $1064 \mathrm{~nm}$, as well as for the inelastically backscattered photons at 387 and $607 \mathrm{~nm}$, which correspond to the Raman shift by nitrogen molecules at 355 and $532 \mathrm{~nm}$, respectively. Additionally, the cross-polarized component of radiation at 355 and $532 \mathrm{~nm}$ is detected, allowing for the determination of the particle linear depolarization ratio (also called depolarization ratio). In this study, the polarization channels permit us to identify nonspherical dust particles from the near-spherical marine aerosols. The Polly ${ }^{X T}$ Arielle system used in this study has been provided by TROPOS.

The vertical resolution of the signal profiles is $30 \mathrm{~m}$, and the raw data are typically stored as $30 \mathrm{~s}$ average values. Data were collected on the web page of PollyNET (http://polly. tropos.de, last access: February 2020) where the "quicklooks" of all measurements are available.

Lidar data were collected during the CHARADMExp campaign (CHARacterization of Aerosol mixtures of Dust and Marine origin Experiment) that took place from 20 June 2014 until 20 July 2014. CHARADMExp was an experimental campaign of the ESA, implemented by the National Observatory of Athens (NOA), and aimed to characterize dust and marine particles along with their mixtures (http: 
//charadmexp.gr, last access: February 2020). The site for the campaign is the ACTRIS (Aerosols, Clouds and Trace gases Research Infrastructure) monitoring station of Finokalia in Greece as presented in Fig. 2. Finokalia station is located at a remote coastal site in the northeast of the island of Crete, Greece, in the Eastern Mediterranean $\left(35.338^{\circ} \mathrm{N}, 25.670^{\circ} \mathrm{E}\right.$; $252 \mathrm{~m}$ a.s.l.). The station is located at a hilltop, facing the sea within a sector from 270 to $90^{\circ}$. No touristic or other human activities can be found at a distance shorter than $15 \mathrm{~km}$ within the aforementioned sector. The site is affected by marine and dust particles $95 \%$ of the time (Mihalopoulos et al., 1997; Kouvarakis et al., 2000).

For the purposes of this study, backscatter coefficient profiles are calculated via the Fernald-Klett method (Fernald, 1984; Klett, 1981). The method requires independent information on the lidar ratio and the reference value of the particle backscatter coefficient. Afterwards, the calibrated depolarization ratio profiles at $532 \mathrm{~nm}$ are calculated (Freudenthaler et al., 2009). An overlap correction was applied on the basis of a simple technique proposed by Wandinger and Ansmann (2002). Thus, the aerosol profiles are retrieved down to $500 \mathrm{~m}$. Extinction coefficient profiles at $532 \mathrm{~nm}$ are also retrieved based on the Raman method (Ansmann et al., 1992), and they are only used for validation purposes of the proposed methodology at a later stage in this study.

\subsection{Models}

Four-day backward trajectories are calculated using the HYbrid Single-Particle Lagrangian Integrated Trajectory model (HYSPLIT) to gather information about the origin of the observed aerosols and the synoptic patterns corresponding to the measurements. The HYSPLIT 4 model is a complete system for computing simple trajectories for complex dispersion and deposition simulations using either puff or particle approaches. A discussion of the model is given by Draxler and Hess (1997) and Draxler and Hess (1998). The simulations were performed using the GDAS (Global Data Assimilation System) meteorological data. Backward trajectories were computed for several altitudes for the CHARADMExp campaign period, confirming that the origin of the air masses arriving over our site were from the Saharan region. The BSC-DREAM8b model is additionally used to verify the presence of Saharan dust, indicated from the trajectory analysis. The BSC-DREAM8b model described the desert dust emissions and transport (Nickovic et al., 2001; Pérez et al., 2006; Basart et al., 2012). Moreover, sea-salt emissions and transport are described with the atmospheric model RAMS/ICLAMS (Solomos et al., 2011). The model is a further-developed version of RAMS 6.0 (Pielke et al., 1992) that allows for a fully prognostic treatment of the seasalt particles and their life cycle in the atmosphere. The simulations were used to verify the presence of marine aerosols in the atmosphere during the campaign and specifically during the day under study.

\section{Results}

\subsection{CHARADMExp lidar measurements}

The range-corrected signal (RCS) at $1064 \mathrm{~nm}$ as a function of time and height is presented in Fig. 3a. The aerosol load inside the planetary boundary layer (PBL) was enhanced throughout the campaign period, while the free tropospheric aerosol load seems to vary with time. Volume depolarization ratio (Fig. 3b) highlights the presence of several depolarizing layers during the campaign, indicating the existence of nonspherical particles. Backward trajectory analysis has confirmed that the origin of these nonspherical particles is from the Saharan region. The lidar observations show that the dust events developed in the free troposphere to end up within the PBL after some days. Thus, the RCS within the PBL appears larger after each dust event. Specifically, there are three intense dust events: the first event took place during 17 and 18 June 2014 at heights up to $5 \mathrm{~km}$. Volume depolarization ratio was maximum during these days with values up to $35 \%$. The second dust event started at noon of 24 June 2014 at the height of $2 \mathrm{~km}$ and within a day the layer had reached up to $5.5 \mathrm{~km}$. This dust event lasted more than $4 \mathrm{~d}$, while several smaller (in terms of intensity) events followed. The third dust event started on 5 July 2014. This dust layer appeared thin with strong volume depolarization ratio and remained thin but unstable in height for almost $3 \mathrm{~d}$. Then this thin layer seemed to expand up to $6 \mathrm{~km}$. The third event was followed by clouds. The remaining days of the campaign appeared with low volume depolarization ratios, indicating almost spherical particles throughout the atmospheric column.

\subsection{Application to a case study: dust and marine aerosol mixture}

We apply the ElEx methodology for the measurement performed on the night of 28 June 2014. The case study was selected based on several criteria: (1) the direction of the air masses indicates dust transport from the Saharan region and possible mixture of marine aerosols as well; (2) values of the linear particle depolarization ratio are within $5 \%$ and $30 \%$, revealing again possible a mixture of dust and marine aerosols; (3) large aerosol load that leads to large SNR (signal-to-noise ratio) which make Raman retrievals possible; and (4) the availability of Cimel sun photometer data during that day. Criterion (3) gives us the opportunity to compare our methodology to concurrent results of extinction profiles with the well-established Raman method, while criterion (4) is used to compare our daytime extinction profile retrieval with an independent instrument.

Four-day backward trajectories arriving at Finokalia station on 28 June 2014 at 02:00 UTC are presented in Fig. 4. The trajectories are computed for arrival heights of 500 (red), 2000 (blue) and $4000 \mathrm{~m}$ (green) to cover the height range of the observed layers that we recognize in coherent structures 


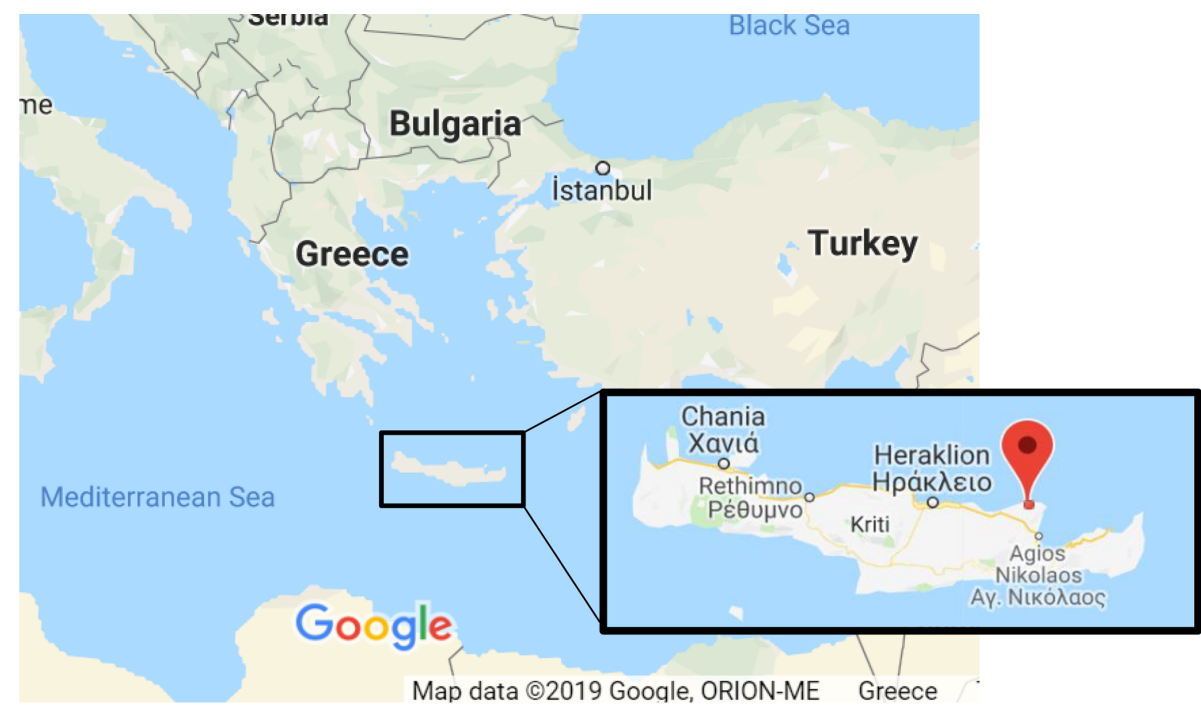

Figure 2. Location of Finokalia station (red dot) in Crete, Greece.
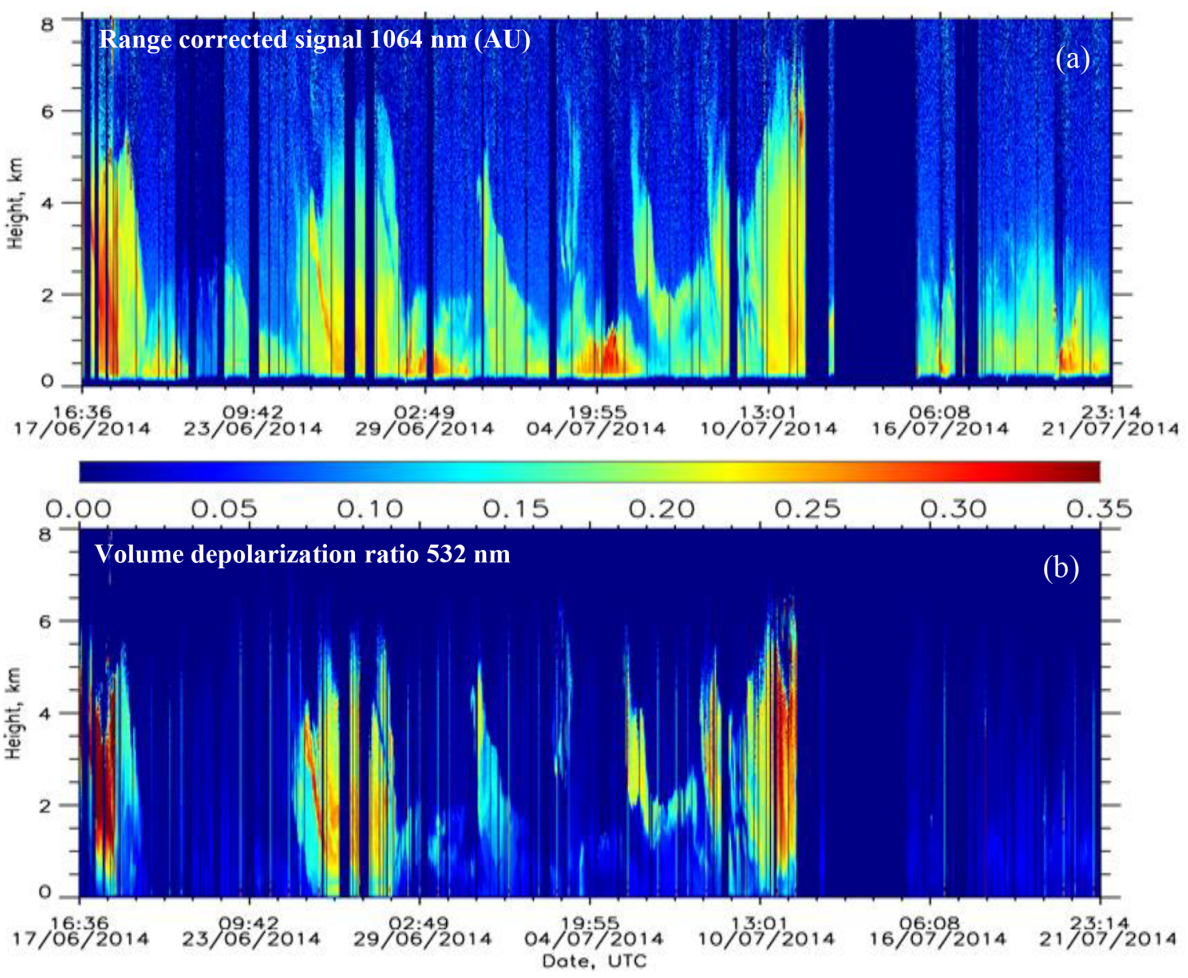

Figure 3. Range-corrected signal at $1064 \mathrm{~nm}$ (a) and volume depolarization ratio (b) at Finokalia during the CHARADMExp campaign.

of height time displays of the range-corrected lidar signal (Fig. 3a). The trajectory analysis reveals that it is highly possible that the air masses carry marine aerosols at Finokalia station on the day under study, especially in lower heights (500 $\mathrm{m}$ arrival height). Trajectory analysis suggests also that dust particles are advected over Finokalia station. Mass concentration profiles performed with the RAMS/ICLAMS and DREAM/BSC models are presented in Fig. 5, and they also confirm the presence of marine aerosol at heights up to $2.5 \mathrm{~km}$ and dust particles up to $5 \mathrm{~km}$. Mean sea-salt concentrations reach $60 \mu \mathrm{g} \mathrm{m}^{-3}$ at the first $200 \mathrm{~m}$, decreasing with height. On the contrary, the dust mean mass concentrations appear to increase with height, taking the maximum value of $70 \mathrm{\mu g} \mathrm{m}^{-3}$ at $\sim 1300 \mathrm{~m}$.

The application of the ElEx methodology was performed in $3 \mathrm{~h}$ averaged lidar signals (00:00-03:00 UTC). The 
NOAA HYSPLIT model

Backward trajectories ending at 02:00 UTC 28 Jun 14

GDAS meteorological data

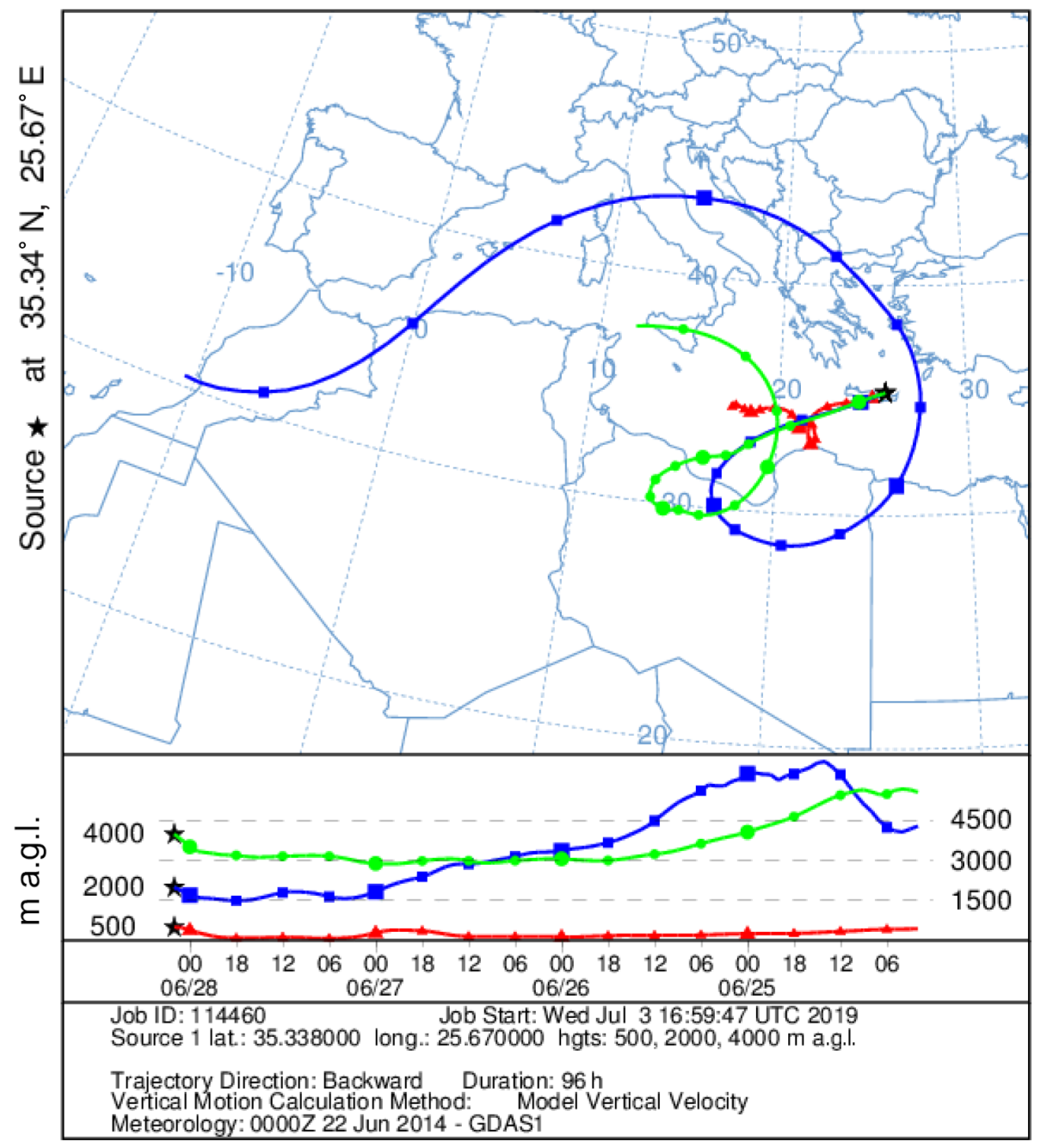

Figure 4. Four-day backward trajectories at 02:00 UTC on 28 June 2014 at Finokalia, Crete. The arrival heights are set to 500, 2000, and $4000 \mathrm{~m}$.

backscatter coefficient, using the Klett-Fernald method with initial lidar ratio of $40 \mathrm{sr}$ (Fernald, 1984; Klett, 1981), was retrieved, and it is presented in Fig. 6a with a black line. A double-layer structure was observed. The first layer occurred between 1.4 and $2.8 \mathrm{~km}$ and the second one, less intense in terms of aerosol load, between 3 and $5 \mathrm{~km}$. The particle depolarization ratio was measured between $15 \%$ and $30 \%$, throughout the atmospheric column, as shown in Fig. 6 with a green line. The separation of the two aerosol types was applied, and the resolved dust and marine backscatter coefficients are presented in Fig. 6b. The dust backscatter coefficient is following the double-layer structure, while marine particles contribute less to the total aerosol load. Appropriate lidar ratios were then used for the estimation of the separated extinction coefficient (see Table 1 and Fig. 2) and the esti- mation of the final retrieval of total extinction coefficient. At the same time frame, Raman extinction coefficient profiles were computed. The results are presented in Fig. 6c. Comparison between Raman and the proposed methodology shows a very good agreement. In addition, the derived extinction coefficient using the proposed methodology has less noise, because it is based on the elastic signal. The retrieval of extinction profiles with low temporal resolution is one of the advantages of the ElEx methodology.

A small difference is observed between the two extinction coefficient profiles at heights greater than $2.8 \mathrm{~km}$. We believe that the aerosol particles of anthropogenic origin are more probable at these heights rather than marine aerosols. Anthropogenic aerosols do not depolarize the light, and thus the value of 0.05 that was used fits well for the separation of dust 


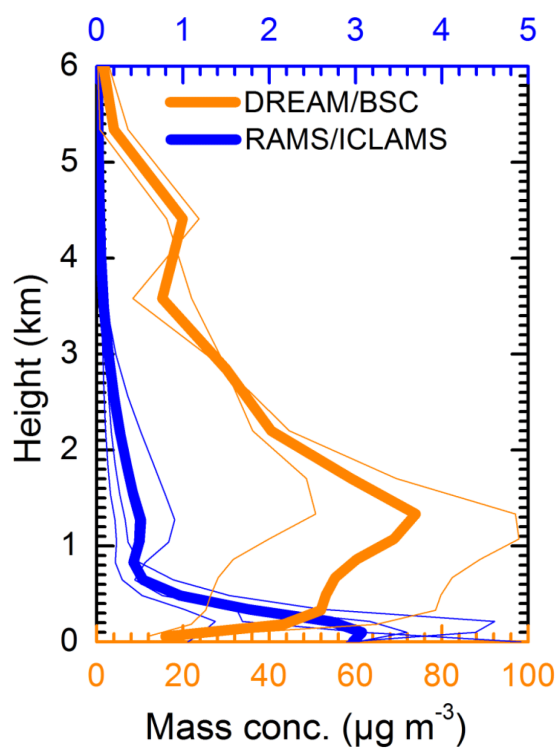

Figure 5. Simulations of sea-salt (blue) and dust (orange) mass concentration profiles using RAMS/ICLAMS and DREAM/BSC models for 28 June 2014, 00:00-03:00 UTC.

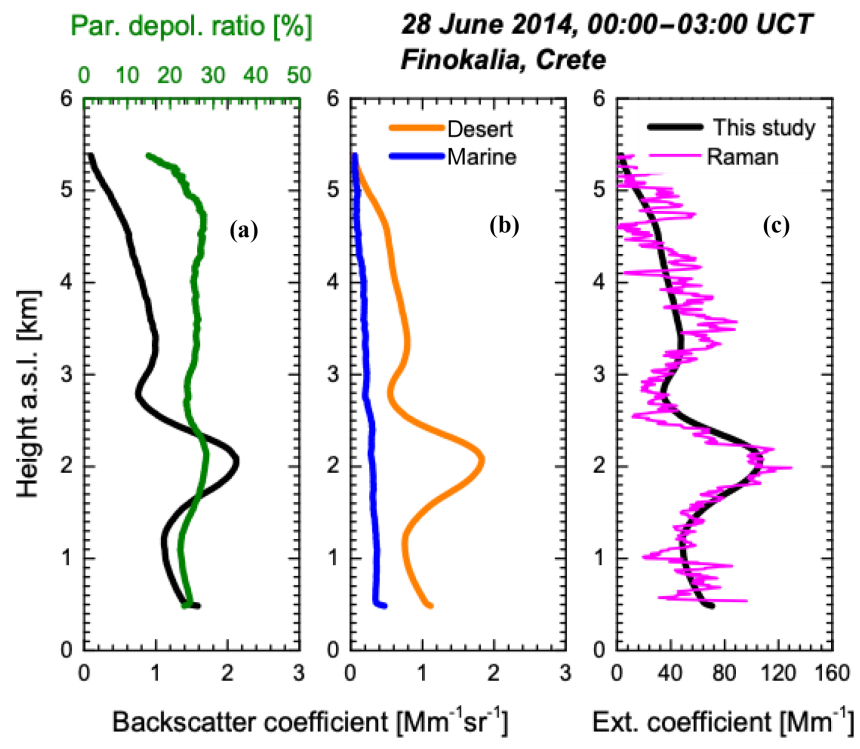

Figure 6. (a) Backscatter coefficient (black) and particle depolarization ratio (green) at $532 \mathrm{~nm}$ for 28 June 2014, 00:00-03:00 UTC. (b) Backscatter coefficient for desert dust (orange) and marine (blue) particles. (c) Extinction coefficient at $532 \mathrm{~nm}$ with the proposed method (black) and using the standard Raman retrieval (pink).

and nondust particles in general. However, for the retrieval of the extinction coefficient profile, the aerosol-type-dependent lidar ratio is crucial. Thus, for heights above $2.8 \mathrm{~km}$, a value of $60 \mathrm{sr}$ (Müller et al., 2007) would lead to better comparison with Raman retrievals.

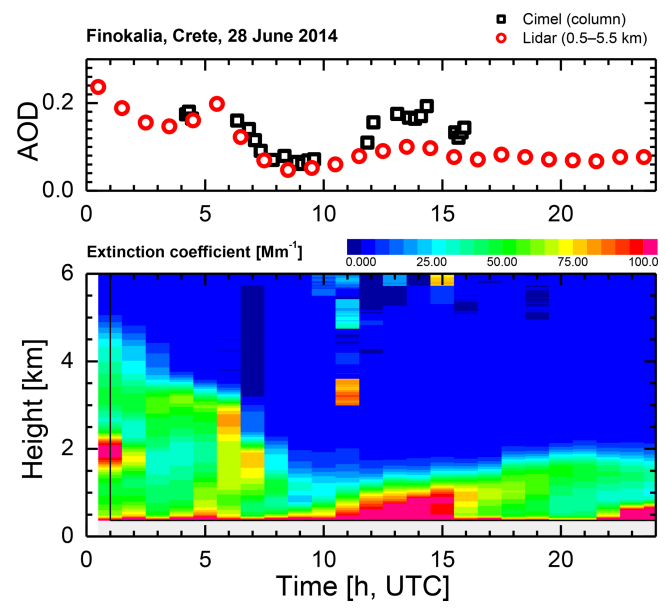

Figure 7. Time series of the aerosol optical depth at $532 \mathrm{~nm}$ from sun photometer data (total column) and from lidar retrieval (0.5$5.5 \mathrm{~km}$ ). Color plot of the extinction coefficient for 28 June 2014.

The second advantage of the ElEx methodology is the ability to check the purity of the nondust component when Raman retrievals are also available.

A 30 min average backscatter coefficient analysis has been performed for the whole case study day based on the KlettFernald algorithm, along with the respective particle depolarization retrievals. For validation purposes, we use the aerosol optical depth of level 2, version 3 AERONET (AErosol RObotic NETwork) sun photometer data. The total columnar aerosol optical depth is compared with the lidar-derived aerosol optical depth, retrieved from integrating the aerosol extinction profiles from 0.5 to $5.5 \mathrm{~km}$. To retrieve the Cimel sun photometer aerosol optical depth at $532 \mathrm{~nm}$, we use the measured aerosol optical depth at $500 \mathrm{~nm}$ and the Ångström exponent between 440 and $870 \mathrm{~nm}$. The results are presented in Fig. 7. The results show reasonable agreement between 04:00 and 10:00 UTC. There is a noticeable difference between the two datasets after 11:00 UTC. This is probably due to larger aerosol load in the first $0.5 \mathrm{~km}$, which is not considered in the lidar aerosol optical depth retrieval. This can be seen from the time evolution of the extinction coefficient at the same day presented in Fig. 7b. The plot shows that after 11:00 UTC there is enhanced aerosol load between 0.5 and $1 \mathrm{~km}$. Thus, there is an indication that the aerosol load could be also enhanced in the lower part of the atmosphere between 0 and $0.5 \mathrm{~km}$. Although AOD (aerosol optical depth) cannot be retrieved in these height ranges due to incomplete overlap, the observed small differences could be attributed to the large aerosol load in the lower boundary layer. The possibility of the retrieval of extinction profiles during daytime with a single-wavelength lidar system is the third advantage of the ElEx methodology.

The quality of the extinction coefficient retrieved by ElEx is depending on the validity of the assumptions made. Firstly, an appropriate lidar ratio assumption is crucial for the re- 

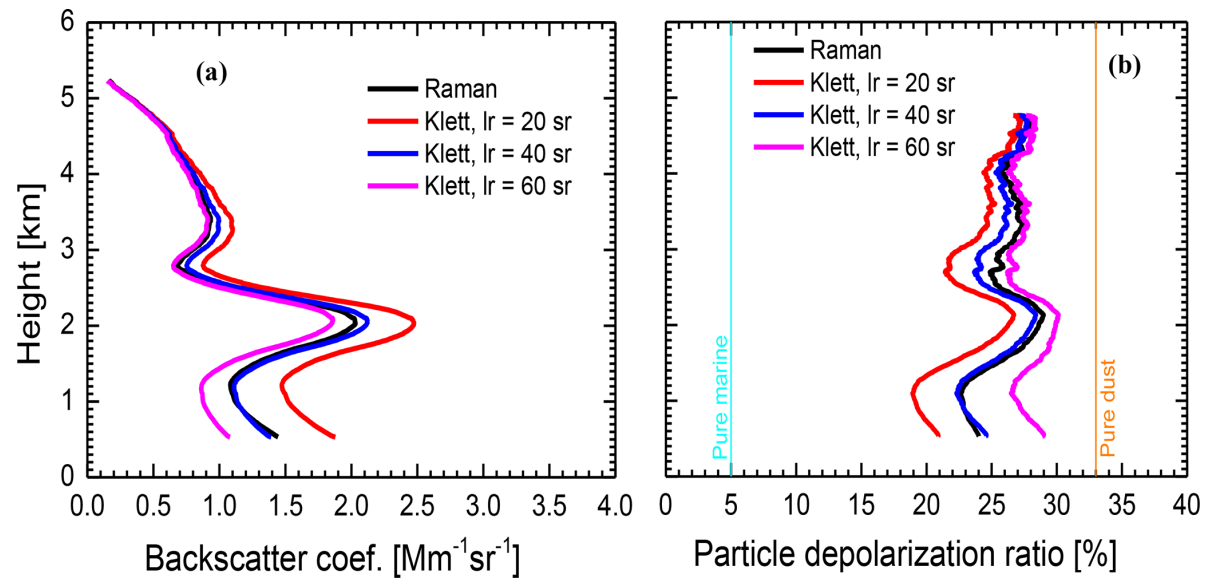

Figure 8. (a) The backscatter coefficient for different lidar ratio initial values for Klett and Raman retrievals and (b) the corresponding particle depolarization ratio profiles.

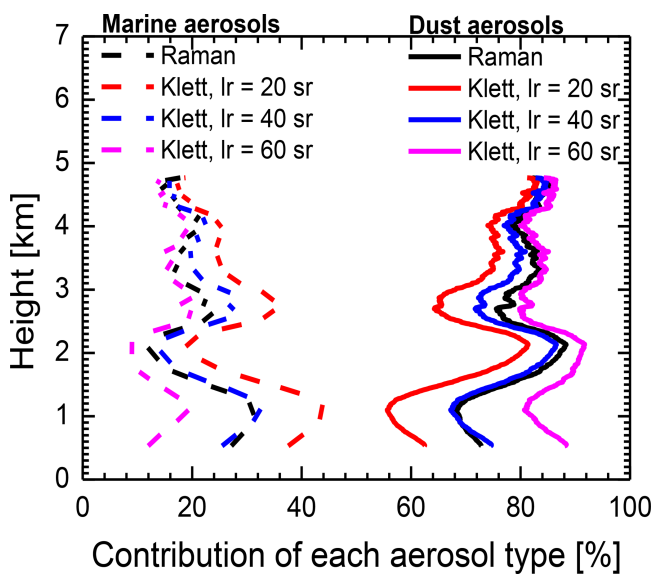

Figure 9. Fraction of marine (dotted) and dust (solid) aerosols based on lidar ratio selection on Klett retrieval and the fraction calculated based on the Raman-based technique (black).

trieval of a realistic backscatter coefficient. In the case under study the assumption of $40 \mathrm{sr}$ is reasonable, taking into account the mixing state of the atmosphere. This is also confirmed by the Raman backscatter coefficient retrieval shown in Fig. 8b. However, a different assumption of $20 \mathrm{sr}$ (or $60 \mathrm{sr}$ ) (which are both extreme values for our case study) will increase (or decrease) the backscatter coefficient at height ranges between 1 and $2 \mathrm{~km}$ (Fig. 8a). The difference would be smaller at higher levels. This assumption will afterwards affect the calculation of the particle depolarization (Fig. 6b) and thus the contribution of the aerosol types involved (Fig. 5). At ranges between 1 and $2 \mathrm{~km}$ a lidar ratio of $20 \mathrm{sr}$ will modify the particle depolarization ratio from $25 \%$ to $20 \%$, while a selection of $60 \mathrm{sr}$ will increase the particle depolarization ratio from $25 \%$ to $30 \%$. Thus, the choice of lidar ratio will affect the fraction of marine and dust particles calculated as shown in Fig. 5. Changing the lidar ratio from
20 to 60 sr will result in differences of $40 \%$ for the contribution for dust particles in the lower part of the atmosphere. The proper selection of depolarization and lidar ratio values for vertical separation has been discussed in previous publications (e.g., Giannakaki et al., 2011; Groß et al., 2011). However, it should be strongly emphasized that the choice of lidar ratio for the final fraction of the aerosol mixture when the Tesche et al. (2009) method is used is critical, especially in the cases of elastic lidars.

In our particular case, the assumptions that were made proved to be reasonable, taking into account the trajectory analysis and the values usually observed for marine and dust particles; thus, the comparison with Raman retrievals shows only very small differences (Fig. 2c). The application of the methodology in more complicated environments is also possible if great attention to the aerosol mixing state and the initial values of the input parameters involved is given.

\section{Conclusions}

In this study we present a new method (ElEx) for the estimation of extinction coefficient lidar profiles with elastic depolarization lidars. ElEx make uses of the elastic backscatter coefficient in combination with depolarization ratio in the same wavelength, along with values of depolarization ratio and lidar ratio based on the literature. Reasonable agreement was found both with Raman retrievals during nighttime and with Cimel sun photometer observations in terms of aerosol optical depth during daytime. This method can be only applied for stations with well-defined aerosol mixtures. There are several advantages to the proposed methodology. ElEx is not limited to nighttime Raman observations, and thus it is applicable to daytime lidar measurement with small time period analysis. In the case of Raman extinction profile availability, the purity of the nondust component can be additionally checked. In stations with more complicated aerosol mix- 
tures within the planetary boundary layer, it is possible to apply the methodology to free tropospheric aerosol layers. CALIPSO extinction retrieval could be also improved when the aerosol mixture is known. However, attention should be given when the separation method is used in elastic backscatter retrievals, regarding not only the depolarization ratio values but also the lidar ratio values selected.

Data availability. Lidar data are available upon request from the authors and data quicklooks are available on the PollyNET website (http://polly.tropos.de/, Leibniz Institute for Tropospheric Research, 2020). Trajectories are calculated with the NOAA (National Oceanic and Atmospheric Administration) HYSPLIT ( HYbrid Single-Particle Lagrangian Integrated Trajectory) model (https:// www.ready.noaa.gov/hypubout/trajplot_145869.pdf, last access: 30 April 2019). BSC-DREAM8b model simulations are operated by the Barcelona Supercomputing Center and are available at https: //ess.bsc.es/bsc-dust-daily-forecast/ (last access: 30 April 2019). The RAMS model can be found at ftp://ftp.mg.uoa.gr/pub/data/ iclams 1.3.tbz (Bartsotas, 2020).

Author contributions. EG developed the methodology and wrote the article. EG, PK, and EM performed the lidar data analysis. NSB analyzed the model simulations. VA and AA initiated the measurement campaign. All authors participated in scientific discussions on this study and reviewed and edited the article during its preparation process.

Competing interests. The authors declare that they have no conflict of interest.

Acknowledgements. The CHARADMExp campaign was funded from the ESA-ESTEC project "CHARacterization of Aerosol mixtures of Dust and Marine origin Experiment" (contract no. IPL$\mathrm{PSO} / \mathrm{FF} / \mathrm{lf} / 14.489$ ). BSC-DREAM8b simulations were performed on the Mare Nostrum supercomputer hosted by the Barcelona Supercomputing Center (Centro Nacional de Supercomputación) (BSC). Eleni Marinou acknowledges the support of the German Academic Exchange Service (Deutscher Akademischer Austauschdienst, grant no. 57370121). Vassilis Amiridis acknowledges the support of the European Research Council (ERC) under the European Community's Horizon 2020 research and innovation framework program - ERC grant agreement 725698 (D-TECT). We acknowledge the support of the "PANhellenic infrastructure for Atmospheric Composition and climatE chAnge" (MIS 5021516), which is implemented under the action "Reinforcement of the Research and Innovation Infrastructure", funded by the operational program "Competitiveness, Entrepreneurship and Innovation" (NSRF 20142020) and co-financed by Greece and the European Union (European Regional Development Fund). The NOA team acknowledges the support of the Stavros Niarchos Foundation (SNF).
Financial support. This research has been supported by the Academy of Finland (project no. 270108).

Review statement. This paper was edited by Andrew Sayer and reviewed by three anonymous referees.

\section{References}

Althausen, D., Engelmann, R., Baars, H., Heese, B., Ansmann, A., and Müller, D.: Portable Raman lidar PollyXT for automated profiling of aerosol backscatter, extinction, and depolarization, J. Atmos. Oceanic Technol., 26, 2366-2378, https://doi.org/10.1175/2009JTECHA1304.1, 2009.

Amiridis, V., Balis, D. S., Kazadzis, S., Bais, A., Giannakaki, E., Papayannis, A., and Zerefos, C.: Four-year aerosol observations with a Raman lidar at Thessaloniki, Greece, in the framework of European Aerosol Research Lidar Network (EARLINET), J. Geophys. Res., 110, D21203, https://doi.org/10.1029/2005JD006190, 2005.

Amiridis, V., Balis, D. S., Giannakaki, E., Stohl, A., Kazadzis, S., Koukouli, M. E., and Zanis, P.: Optical characteristics of biomass burning aerosols over Southeastern Europe determined from UVRaman lidar measurements, Atmos. Chem. Phys., 9, 2431-2440, https://doi.org/10.5194/acp-9-2431-2009, 2009.

Ansmann, A., Wandinger, U., Riebesell, M., Weitkamp, C., and Michaelis, W.: Independent measurement of extinction and backscatter profiles in cirrus clouds by using a combined Raman elastic-backscatter lidar, Appl. Opt., 31, 7113-7131, 1992.

Ansmann, A., Wagner, F., Althausen D., Müller, D., Herber, A., and Wandinger, U.: European pollution outbreaks during ACE 2: Lofted aerosol plumes observed with Raman lidar at the Portuguese coast, J. Geophys. Res., 106, 20725-20733, 2001.

Ansmann, A., Wagner, F., Müller, D., Althausen, D., Herber, A., von Hoyningen-Huene, W., and Wandinger U.: European pollution outbreaks during ACE 2: Optical particle properties inferred from multiwavelength lidar and star-Sun photometry, J. Geophys. Res., 107, 4259, https://doi.org/10.1029/2001JD001109, 2002.

Ansmann, A., Tesche, M., Seifert, P., Groß, S., Freudenthaler, V., Apituley, A., Wilson, K.M., Serikov, I., Linné, H., Heinold, B., Hiebsch, A., Schnell, F., Schmidt, J., Mattis, I., Wandinger, U., and Wiegner, M.: Ash and fine-mode particle mass profiles from EARLINET-AERONET observations over central Europe after the eruptions of the Eyjafjallajökull volcano in 2010, J. Geophys. Res., 116, D00U02, https://doi.org/10.1029/2010JD015567, 2011.

Ansmann, A., Rittmeister, F., Engelmann, R., Basart, S., Jorba, O., Spyrou, C., Remy, S., Skupin, A., Baars, H., Seifert, P., Senf, F., and Kanitz, T.: Profiling of Saharan dust from the Caribbean to western Africa - Part 2: Shipborne lidar measurements versus forecasts, Atmos. Chem. Phys., 17, 14987-15006, https://doi.org/10.5194/acp-17-14987-2017, 2017.

Ansmann, A., Mamouri, R.-E., Hofer, J., Baars, H., Althausen, D., and Abdullaev, S. F.: Dust mass, cloud condensation nuclei, and ice-nucleating particle profiling with polarization lidar: updated POLIPHON conversion factors from global 
AERONET analysis, Atmos. Meas. Tech., 12, 4849-4865, https://doi.org/10.5194/amt-12-4849-2019, 2019.

Baars, H., Ansmann, A., Althausen, D., Engelmann, R., Heese, B., Müller, D., Artaxo, P., Paixao, M., Pauliquevis, T., and Souza, R.: Aerosol profiling with lidar in the Amazon Basin during the wetand dry season, J. Geophys. Res., 117, D21201, https://doi.org/10.1029/2012JD018338, 2012.

Baars, H., Kanitz, T., Engelmann, R., Althausen, D., Heese, B., Komppula, M., Preißler, J., Tesche, M., Ansmann, A., Wandinger, U., Lim, J.-H., Ahn, J. Y., Stachlewska, I. S., Amiridis, V., Marinou, E., Seifert, P., Hofer, J., Skupin, A., Schneider, F., Bohlmann, S., Foth, A., Bley, S., Pfüller, A., Giannakaki, E., Lihavainen, H., Viisanen, Y., Hooda, R. K., Pereira, S. N., Bortoli, D., Wagner, F., Mattis, I., Janicka, L., Markowicz, K. M., Achtert, P., Artaxo, P., Pauliquevis, T., Souza, R. A. F., Sharma, V. P., van Zyl, P. G., Beukes, J. P., Sun, J., Rohwer, E. G., Deng, R., Mamouri, R.-E., and Zamorano, F.: An overview of the first decade of PollyNET: an emerging network of automated Raman-polarization lidars for continuous aerosol profiling, Atmos. Chem. Phys., 16, 5111-5137, https://doi.org/10.5194/acp16-5111-2016, 2016.

Balis, D., Amiridis, V., Zerefos, C. S., Gerasopoulos, E., Meinrat, A., Zanis, P., Kazantzidis, A., Kazadzis, S., and Papayannis, A.: Raman lidar and sunphotometric measurements of aerosoloptical properties over Thessaloniki, Greece duringa biomass burning episode, Atmos. Environ., 37, 4529-4538, 2003.

Balis, D. S., Amiridis, V., Zerefos, C., Kazantzidis, A., Kazadzis, S., Bais, A. F., Meleti, C., Gerasopoulos, E., Papayannis, A., Matthias, V., Dier, H., and Andreae, M. O.: Study of the effect of different type of aerosols on UV-B radiation from measurements during EARLINET, Atmos. Chem. Phys., 4, 307-321, https://doi.org/10.5194/acp-4-307-2004, 2004.

Bartsotas, N. S.: RAMS/ICLAMS mass concentration profiles, available at: ftp://ftp.mg.uoa.gr/pub/data/iclams1.3.tbz, last access: 10 February 2020.

Basart, S., Pérez, C., Nickovic, S., Cuevas, E., and Baldasano, J. M.: Development and evaluation of the BSCDREAM8B8b dust regional model over Northern Africa, the Mediterranean and the Middle East, Tellus B, 64, https://doi.org/10.3402/tellusb.v64i0.18539, 2012.

Burton, S. P., Ferrare, R. A., Hostetler, C. A., Hair, J. W., Rogers, R. R., Obland, M. D., Butler, C. F., Cook, A. L., Harper, D. B., and Froyd, K. D.: Aerosol classification using airborne High Spectral Resolution Lidar measurements - methodology and examples, Atmos. Meas. Tech., 5, 73-98, https://doi.org/10.5194/amt-5-732012, 2012.

Burton, S. P., Ferrare, R. A., Vaughan, M. A., Omar, A. H., Rogers, R. R., Hostetler, C. A., and Hair, J. W.: Aerosol classification from airborne HSRL and comparisons with the CALIPSO vertical feature mask, Atmos. Meas. Tech., 6, 13971412, https://doi.org/10.5194/amt-6-1397-2013, 2013.

Dawson, K. W., Meskhidze, N., Josset, D., and Gassó, S.: Spaceborne observations of the lidar ratio of marine aerosols, Atmos. Chem. Phys., 15, 3241-3255, https://doi.org/10.5194/acp15-3241-2015, 2015.

Draxler, R. R. and Hess, G. D.: Description of the HYSPLIT 4 modeling system, NOAA Tech Memo, ERL ARL-224, NOAA, Silver Spring, MD, 1997.
Draxler, R. R. and Hess, G. D.: An overview of the HYSPLIT 4 modelling system for trajectories, dispersion and deposition, Austral. Meteorol. Mag., 47, 295-308, 1998.

Engelmann, R., Kanitz, T., Baars, H., Heese, B., Althausen, D., Skupin, A., Wandinger, U., Komppula, M., Stachlewska, I. S., Amiridis, V., Marinou, E., Mattis, I., Linné, H., and Ansmann, A.: The automated multiwavelength Raman polarization and water-vapor lidar PollyXT: the neXT generation, Atmos. Meas. Tech., 9, 1767-1784, https://doi.org/10.5194/amt-9-1767-2016, 2016.

Fernald, F. G.: Analysis of atmospheric lidar observations: some comments, Appl. Opt., 23, 652-653, https://doi.org/10.1364/AO.23.000652, 1984.

Freudenthaler, V., Esselborn, M., Wiegner, M., Heese, B., Tesche, M., Ansmann, A., Müller, D., Althausen, D., Wirth, M., Fix, A., Ehret, G., Knippertz, P., Toledano, C., Gasteiger, J., Garhammer, M., and Seefeldner M.: Depolarization ratio profiling at several wavelengths in pure Saharan dust during SAMUM 2006, Tellus B, 61, 165-179, https://doi.org/10.1111/j.16000889.2008.00396.x, 2009.

Giannakaki, E., Balis, D. S., Amiridis, V., and Zerefos, C: Optical properties of different aerosol types: seven years of combined Raman-elastic backscatter lidar measurements in Thessaloniki, Greece, Atmos. Meas. Tech., 3, 569-578, https://doi.org/10.5194/amt-3-569-2010, 2010.

Giannakaki, E., Balis, D., and Amiridis, V.: Vertical resolved separation of aerosol types using CALIPSO level-2 product, Proc. SPIE 8182, Lidar Technologies, Techniques, and Measurements for Atmospheric Remote Sensing VII, 81820T, SPIE Remote Sensing, 2011, Prague, Czech Republic, https://doi.org/10.1117/12.898095, 2011.

Giannakaki, E., van Zyl, P. G., Müller, D., Balis, D., and Komppula, M.: Optical and microphysical characterization of aerosol layers over South Africa by means of multi-wavelength depolarization and Raman lidar measurements, Atmos. Chem. Phys., 16, 81098123, https://doi.org/10.5194/acp-16-8109-2016, 2016.

Giannakaki, E., Kokkalis, P., Marinou, E., Solomos, S., Amiridis, V., Ansmann, A., Bartsotas, N., Engelmann, R., and Komppula, M.: Extinction profile retrieval at Finokalia, Crete, in the proceedings of 28th International Laser and Radar Conference, Bucharest, Romania, 2017.

Groß, S, Tesche, M., Freudenthaler, V., Toledano, C., Wiegner, M., Ansmann, A., Althausen, D., and Seefeldner, M.: Characterization of Saharan dust, marine aerosols and mixtures of biomassburning aerosols and dust by means of multi-wavelength depolarization and Raman lidar measurements during SAMUM 2, Tellus B, 63, 706-724, 2011.

Groß, S., Esselborn, M., Weinzierl, B., Wirth, M., Fix, A., and Petzold, A.: Aerosol classification by airborne high spectral resolution lidar observations, Atmos. Chem. Phys., 13, 2487-2505, https://doi.org/10.5194/acp-13-2487-2013, 2013.

Groß, S., Freudenthaler, V., Schepanski, K., Toledano, C., Schäfler, A., Ansmann, A., and Weinzierl, B.: Optical properties of long-range transported Saharan dust over Barbados as measured by dual-wavelength depolarization Raman lidar measurements, Atmos. Chem. Phys., 15, 11067-11080, https://doi.org/10.5194/acp-15-11067-2015, 2015.

Heese, B., Althausen, D., Baars, H., Bohlmann, S., and Deng, R.: Aerosol Properties over Southeastern China from Multi- 
Wavelength Raman and Depolarization Lidar Measurements, EPJ Web of Conferences, The 27th International Laser Radar Conference (ILRC 27), New York, USA, 23018, 2016.

IPCC: Climate Change 2013: The Physical Science Basis, Contribution of Working Group I to the Fifth Assessment Report of the Intergovernmental Panel on Climate Change, edited by: Stocker, T. F., Qin, D., Plattner, G.-K., Tignor, M., Allen, S. K., Boschung, J., Nauels, A., Xia, Y., Bex, V., and Midgley, P. M., Cambridge University Press, Cambridge, United Kingdom and New York, NY, USA, https://doi.org/10.1017/CBO9781107415324, 2013.

Jaenicke, R. and Schutz, L.: Comprehensive Study of Physical and Chemical Properties of the Surface Aerosols in the Cape Verde Islands Region, J. Geophys. Res., 83, 3585-3599, 1978.

Kaufman, Y. J., Tanre, D., and Boucher, O.: A satellite view of aerosols in the climate system, Nature, 419, 215-223, https://doi.org/10.1038/nature01091, 2002.

Klett, J. D.: Stable analytical inversion solution for processing lidar returns, Appl. Opt. 20, 211-220, https://doi.org/10.1364/AO.20.000211, 1981.

Kokkalis, P., Papayannis, A., Amiridis, V., Mamouri, R. E., Veselovskii, I., Kolgotin, A., Tsaknakis, G., Kristiansen, N. I., Stohl, A., and Mona, L.: Optical, microphysical, mass and geometrical properties of aged volcanic particles observed over Athens, Greece, during the Eyjafjallajökull eruption in April 2010 through synergy of Raman lidar and sunphotometer measurements, Atmos. Chem. Phys., 13, 9303-9320, https://doi.org/10.5194/acp-13-9303-2013, 2013.

Kouvarakis, G., Tsigaridis, K., Kanakidou, M., and Michalopoulos, N.: Temporal variations of surface regional background ozone over Crete Island in the southeast Mediterranean, J. Geophys. Res., 105, 4399-4407, 2000.

Leibniz Institute for Tropospheric Research: Worldwide observations with the portable Raman lidar systems (Polly), available at: http://polly.tropos.de/, last access: February 2020.

Mamouri, R. E., Ansmann, A., Nisantzi, A., Kokkalis, P., Schwarz, A., and Hadjimitsis, D.: Low Arabian dust extinction-tobackscatter ratio, Geophys. Res. Lett., 40, 4762-4766, 2013.

Marinou, E. , Amiridis, V., Binietoglou, I., Tsikerdekis, A. , Solomos, S., Proestakis, E., Konsta, D., Papagiannopoulos, N., Tsekeri, A., Vlastou, G., Zanis, P., Balis, D., Wandinger, U., and Ansmann, A.: Three-dimensional evolution of Saharan dust transport towards Europe based on a 9-year EARLINEToptimized CALIPSO dataset, Atmos. Chem. Phys., 17, 58935919, https://doi.org/10.5194/acp-17-5893-2017, 2017.

Mattis, I., Ansmann, A., Müller, D., Wandinger, U., and Althausen, D.: Multiyear aerosol observations with dual-wavelength Raman lidar in the framework of EARLINET, J. Geophys. Res., 109, D13203, https://doi.org/10.1029/2004JD004600, 2004.

Mattis, I., Siefert P., Müller, D., Tesche, M., Hiebsch, A., Kanitz, T., Schmidt, J., Finger, F., Wandinger, U., and Ansmann, A.: Volcanic aerosol layers observed with multiwavelength Ramanlidar over central Europe in 2008-2009, J. Geophys. Res., 115, D00L04, https://doi.org/10.1029/2009JD013472, 2010.

Mihalopoulos, N., Stephanou, E., Kanakidou, M., Pilitsidis, S., and Bousquet, P.: Tropospheric aerosol ionic composition above Eastern Mediterranean area, Tellus B, 49, 314-326, 1997.

Mona, L., Amodeo, A., Pandolfi, M., and Pappalardo, G.: Saharan dust intrusions in the Mediterranean area: Three years of
Raman lidar measurements, J. Geophys. Res., 111, D16203, https://doi.org/10.1029/2005JD006569, 2006.

Mona, L., Amodeo, A., D’Amico, G., Giunta, A., Madonna, F., and Pappalardo, G.: Multi-wavelength Raman lidar observations of the Eyjafjallajökull volcanic cloud over Potenza, southern Italy, Atmos. Chem. Phys., 12, 2229-2244, https://doi.org/10.5194/acp-12-2229-2012, 2012.

Müller, D., Ansmann, A., Mattis, I., Tesche, M., Wandinger, U., Althausen, D., and Pisani, G.: Aerosol-type-dependent lidar ratios observed with Raman lidar, J. Geophys. Res., 112, D16202, https://doi.org/10.1029/2006JD008292, 2007.

Nickovic, S., Kallos, G., Papadopoulos, A., and Kakaliagou, O.: A model for prediction of desert dust cycle in the atmosphere, J. Geophys. Res., 106, 18113-18129, 2001.

Nicolae, D.: Characterization of fresh and aged biomass burning events using multiwavelength Raman lidar and mass spectrometry, J. Geophys. Res.-Atmos., 118, 2956-2965, 2013.

Nisantzi, A., Mamouri, R. E., Ansmann, A., Schuster, G. L., and Hadjimitsis, D. G.: Middle East versus Saharan dust extinctionto-backscatter ratios, Atmos. Chem. Phys., 15, 7071-7084, https://doi.org/10.5194/acp-15-7071-2015, 2015.

Omar, A.: The CALIPSO Automated Aerosol Classification and Lidar Ratio Selection Algorithm, J. Atmos. Ocean. Technol., 26, 1994-2014, 2009.

Papayannis, A., Balis, D., Amiridis, V., Chourdakis, G., Tsaknakis, G., Zerefos, C., Castanho, A. D. A., Nickovic, S., Kazadzis, S., and Grabowski, J.: Measurements of Saharan dust aerosols over the Eastern Mediterranean using elastic backscatter-Raman lidar, spectrophotometric and satellite observations in the frame of the EARLINET project, Atmos. Chem. Phys., 5, 2065-2079, https://doi.org/10.5194/acp-5-2065-2005, 2005.

Papayannis, A., Amiridis, V., Mona, L., Tsaknakis, G., Balis, D., Bösenberg, J., Chaikovski, A., De Tomasi, F., Grigorov, I., Mattis, I., Mitev, V., Müller, D., Nickovic, S., Perez, C., Pietruczuk, A., Pisani, G., Ravetta, F., Rizi, V., Sicard, M., Trickl, T., Wiegner, M., Gerding, M., Mamouri, R. E., D'Amico, G. and Pappalardo, G.: Systematic lidar observations of Saharan dust over Europe in the frame of EARLINET (2000-2002), J. Geophys. Res.-Atmos. (AGU), 113(D10), D10204, 2008.

Papayannis, A., Mamouri, R. E., Amiridis, V., Giannakaki, E., Veselovskii, I., Kokkalis, P., Tsaknakis, G., Balis, D., Kristiansen, N. I., Stohl, A., Korenskiy, M., Allakhverdiev, K., Huseyinoglu, M. F., and Baykara, T.: Optical properties and vertical extension of aged ash layers over the EasternMediterranean as observed by Raman lidars during the Eyjafjallajökull eruption in May 2010, Atmos. Environ., 48, 56-65, 2012.

Pappalardo, G., Mona, L., D’Amico, G., Wandinger, U., Adam, M., Amodeo, A., Ansmann, A., Apituley, A., Alados Arboledas, L., Balis, D., Boselli, A., Bravo-Aranda, J. A., Chaikovsky, A., Comeron, A., Cuesta, J., De Tomasi, F., Freudenthaler, V., Gausa, M., Giannakaki, E., Giehl, H., Giunta, A., Grigorov, I., Groß, S., Haeffelin, M., Hiebsch, A., Iarlori, M., Lange, D., Linné, H., Madonna, F., Mattis, I., Mamouri, R.-E., McAuliffe, M. A. P., Mitev, V., Molero, F., Navas-Guzman, F., Nicolae, D., Papayannis, A., Perrone, M. R., Pietras, C., Pietruczuk, A., Pisani, G., Preißler, J., Pujadas, M., Rizi, V., Ruth, A. A., Schmidt, J., Schnell, F., Seifert, P., Serikov, I., Sicard, M., Simeonov, V., Spinelli, N., Stebel, K., Tesche, M., Trickl, T., Wang, X., Wagner, F., Wiegner, M., and Wilson, K. M.: Four-dimensional dis- 
tribution of the 2010 Eyjafjallajökull volcanic cloud over Europe observed by EARLINET, Atmos. Chem. Phys., 13, 4429-4450, https://doi.org/10.5194/acp-13-4429-2013, 2013.

Pérez, C., Nickovic, S., Pejanovic, G., Baldasano, J. M., and Özsoy, E.: Interactive dust-radiation modeling: A step to improve weather forecasts, J. Geophys. Res., 111, D16206, https://doi.org/10.1029/2005JD006717, 2006.

Pielke, R. A., Cotton, W. R., Walko, R. L., Tremback, C. J., Lyons, W. A., Grasso, L. D., Nicholls, M. E., Moran, M. D., Wesley, D. A., Lee, T. J., and Copeland, J. H.: A Comprehensive Meteorological Modeling System RAMS, Meteorol. Atmos. Phys., 49, 69-91, 1992.

Prospero, J. M. and Savoie, D. L.: Effect of continental sources on nitrate concentrations over the Pacific Ocean, Lett. Nature, 339, 687-689, 1989.

Sicard, M., Guerrero-Rascado, J. L., Navas-Guzmán, F., Preißler, J., Molero, F., Tomás, S., Bravo-Aranda, J. A., Comerón, A., Rocadenbosch, F., Wagner, F., Pujadas, M., and AladosArboledas, L.: Monitoring of the Eyjafjallajökull volcanic aerosol plume over the Iberian Peninsula by means of four EARLINET lidar stations, Atmos. Chem. Phys., 12, 3115-3130, https://doi.org/10.5194/acp-12-3115-2012, 2012.

Solomos, S., Kallos, G., Kushta, J., Astitha, M., Tremback, C., Nenes, A., and Levin, Z.: An integrated modeling study on the effects of mineral dust and sea salt particles on clouds and precipitation, Atmos. Chem. Phys., 11, 873-892, https://doi.org/10.5194/acp-11-873-2011, 2011.
Tesche, M., Ansmann, A., Müller, D., Althausen, D., Engelmann, R., Freudenthaler, V., and Groß, S.: Vertically resolved separation of dust and smoke over Cape Verde by using multiwavelength Raman and polarization lidars during Saharan Mineral Dust Experiment 2008, J. Geophys. Res., 114, D13202, https://doi.org/10.1029/2009JD011862, 2009.

Valenzuela, A., Olmo, F. J., Lyamani, H., Granados-Muñoz, M. J., Antón, M., Guerrero-Rascado, J. L., Quirantes, A., Toledano, C., Perez-Ramírez, and Alados-Arboledas, L.: Aerosol transport over the western Mediterranean basin: Evidence of the contribution of fine particles to desert dust plumes over Alborán Island, J. Geophys. Res.-Atmos., 201, 14028-14044. 2014.

Wandinger, U. and Ansmann, A.: Experimental determination of the lidar overlap profile with Raman lidar, Appl. Opt., 41, 511-514, 2002.

Wiegner, M., Gro $\beta$, S., Freudenthaler, V., Schnell, F., and Gasteriger, J.: The May/June 2008 Saharan dust event over Munich: Intensive aerosol parameters from lidar measurements. J. Geophys. Res., 116, D23213, https://doi.org/10.1029/2011JD016619, 2012. 